\title{
Synergy of Indigenous Values With Law Number 6 of 2014 Concerning Village: Study on Nagari Kapau Government In West Sumatera
}

\author{
$1^{\text {st }}$ Hasbullah Malau* \\ Universitas Negeri Padang \\ Padang, Indonesia \\ hasbullahmalau@fis.unp.ac.id
}

\author{
$2^{\text {nd }}$ Artha Dini Akmal \\ Universitas Negeri Padang \\ Padang, Indonesia \\ arthadiniakmal@fis.unp.ac.id
}

\begin{abstract}
The implementation of Decentralization practices in Indonesia allows the application of a system of government based on indigenous to be applied at the level of the Village Government or Indigenous Village Government. This study aims to analyze the model of strengthening traditional values that are still maintained and used in the administration of Indigenous Village Government referring to Law Number 6 of 2014 concerning Villages in the Village Government based on local wisdom in West Sumatra. The design of this study were using descriptive qualitative with a case study method. Informants were determined by using a purposive technique on Nagari Kapau as a research objects, in West Sumatra Province. Data collection was carried out by using observations, in-depth interviews, documentation studies and continued with
\end{abstract}

\section{INTRODUCTION}

The Republic of Indonesia respects the rights of the origin of the region and its position [1]. However, the uniformity of villages was carried out based on Law Number 5 of 1979 concerning the Village Government [2], which made the number of villages and indigenous villages unknown to the origin and position. For villages in West Sumatra, namely Nagari, the issuance of Law Number 6 of 2014 concerning Villages [3] as a substitute for Law Number 5 of 1979 concerning Village Government is to strengthen the mention of Nagari as seen from the considerations considering the letter $b$ of Law
Focus Group Discussion (FGD). Checking the validity of the data in this study was carried out using data triangulation techniques. The results of the study prove that customary values that are still maintained and used in the administration of Village/Nagari governance in West Sumatra include (1) Nagari residents have blood ties; (2) Islam's sole religion; (3) has nine tribes; (4) Land-based on the Charter of 1912, 1925, 1955, 1997 and 2003; (5) Niniak Mamak (Chieftain)Owner of Nagari; (6) Customary Courts; (7) Nagari Government Institution and Nagari Customary Institution. The implication of this research is the accommodation of the application of customary values as the application of local wisdom to the Administration of Nagari Government.

Keywords-Synergy, Local Wisdom, Village and Nagari

Number 6 of 2014 which states: that in the course of the Republican administration Indonesia, the village has developed in various forms so it needs to be protected and empowered to be strong, advanced, independent, and democratic so that it can create a strong foundation in carrying out governance and development towards a just, prosperous, and prosperous society.

Indonesia as one of the biggest and largest countries with its cultural heritage will have an important role in transferring cultural elements from generation to generation in order to maintain their identity and fight the influence of westernization which is increasingly covering 
all aspects of Indonesian people's lives, by returning local wisdom and religion as a native culture of the community. Strengthening traditional values with Law Number 6 of 2014 concerning Villages, to strengthen the implementation of the Nagari Government based on local wisdom in West Sumatra.

Go back to studying and understanding his religion and local wisdom, with the hope that at some point there will be broad conformity of opinion that religious beliefs and local wisdom as traditionally understood, will prominently offer values, norms, and intrinsic meaning to some large modern and post-modern societies [4]. Thus, for Preparing Students and Graduates to be Knowledge Workers in Challenging Industrial Revolution 4.0 "(Preparing Students and Graduates to Become Knowledge Workers in Challenging the Industrial Revolution 4.0), it is necessary to understand traditional values with modern and post-modern values in the administration of village and customary villages. Strengthening these indigenous values, built and carried out by the conditions of an area based on the origin rights and traditional rights in managing, regulating the interests of their communities with the hope of a match between customary values and regional autonomy in the administration of custom-based regional govern ment [5].

In line with the birth of Law Number 6 of 2014 concerning Villages, Chapter V Organizing Village Government Article 23 Village Govern ment is organized by the Village Government in Article 24 Organizing Village Government based on the principle (i) of local wisdom. The discourse of strengthening local wisdom, to overcome shifts in cultural and religious values, is not something new in overcoming everyday problems in society. This is in line with the birth of Law Number 6 of 2014 concerning Villages so that local wisdom at the village level is reclaimed after nearly 32 years of experiencing uniformity based on Law Number 5 of 1979 concerning the Village Government, in 1983 Nagari amounting to 453 Nagari was made into a structure of 3516 villages and subsequently reduced to 1700 villages. Finally, the number of Nagari becoming villages is not known with certainty due to the change in the village becoming a village only to get village assistance funds (Bandes) and not all regencies and cities in West Sumatra turn villages into villages like Mentawai districts, for example, the lowest government still uses the term village. This paradigm shift is expected to strengthen the joint principles of local government policies, such as the Nagari Government in West Sumatra, argued: "the return to the Nagari has led to a new interest in adat as a legitimation of political authority" [6].

Provincial Regulation Policy Number 9 of 2000 regarding the basic provisions of the Nagari Government in recognition of the return of the village government based on local wisdom. The aim of decentralization is to create political equality at the local level. Political equality in decentralization is the contribution of streng thening local democracy, where people have a greater chance to vote in elections and decision making, forming political associations and exercising the right to freedom of speech [7].

While on the other hand, the implementation of regional government is based on the concept of six dimensions, namely social, economic, geographical, legal (legal), political and administrative [8]. However, this implemen tation has not considered local wisdom which is the essence of an individual or human being attached to it such as religion and tradition as a synergy of local wisdom values into local government, which is one of the supporting elements of local government theory. Thus, that the use of Nagari's traditional values into the Nagari Government system to ensure the continuity and existence of Nagari as local wisdom so that previous, present and future generations have the same rights and opportunities to enjoy existing local wisdom (Nagari Government). This, along with the rapid economic growth, politics, development, natural resources, agriculture, plantation and tourism industry in West Sumatra, local wisdom is often modified and even traded for economic and political interests.

Thus, that the implementation of the Nagari Government is carried out according to the characteristics of the origin of the region, local culture, local wisdom in accordance with the provisions of Law No. 6 of 2014 concerning 
Villages that are owned and are still maintained to strengthen the running of the Nagari government. Customary values that grow and develop in the Nagari indigenous people and have a synergy with the enactment of Law Number 6 of 2014, which is used in the administration of the Nagari Government to strengthen the running of the Nagari Government which is democratic as the focus of this research. The traditional values that are owned and maintained are the origin rights of the region, religion, ethnicity and elements of local democracy.

\section{METHOD}

This research carried out in a qualitative research design, remembers its purpose to reveal what happened in empirical reality. This study more observes and explores the behavior of the object under study, so finding, understanding, explaining and obtaining about social phenomena related to customary values used in decision making on the administration of Government in Nagari Kapau. This qualitative (naturalistic) research is a way of research to understand the existing reality, social reality, and human perceptions. This approach can reveal real events in the field and can also reveal hidden values, including describing and interpreting an event or phenomenon, so that it can capture the essence of human emotions, feelings, and perceptions in a personal context. Furthermore, it provides specific interpretations and meanings of objects, followed by linking the results of the analysis with existing theories. This means that qualitative methods will contribute to the development of theories and concepts of the object under study [9]. This qualitative approach is expected to get answers to the meaning of urgency.

To explore traditional values as the focus of this research is done by asking the question: What should I learn, and which part should I ignore? One way to direct the focus of this research is to build the proposed perspective according to the research topic. That is, through guidance and the direction of focus that has been determined, can be known by people, which data needs to be collected and which data is not needed [10]. This is done to determine the focus, which is to limit research (the field of inquiry) and meet the criteria for inclusions-exclusionexclusion criteria for information that has just been obtained in the field [11]. Therefore, the data collected in this study are unique to the traditional values (local wisdom) of the Minangkabau community and the Nagari government [12], [13]. In addition to conducting interviews, it also uses documentation studies including scientific literature, regulations, books, inscriptions, journals, newspaper articles, videos, photos, various types of notes, speech papers, case studies, television shows, custom tambo, traditional leaders, intellectuals, scholars, proverbs customs used, report the results of research relevant to this study.

The process of data analysis was carried out using qualitative analysis by following the steps stated by [14], namely the analysis of four concurrent activities (1) data collection; (2) data condensation (3) data display (4) conclusion: drawing/verification. To understand contextually the interactive data analysis model developed by [14], can be explained in the picture as follows:

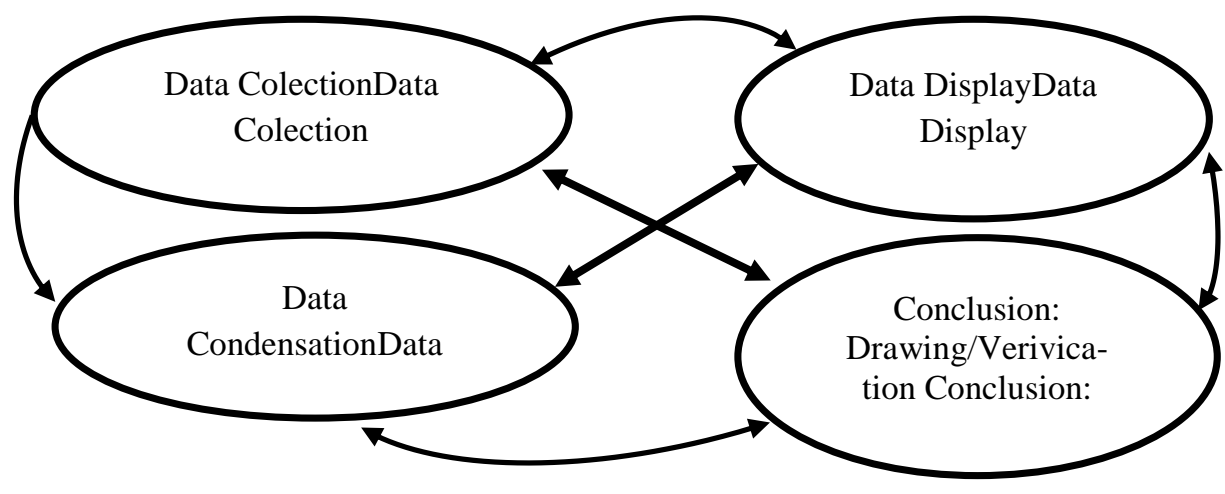

Figure 1. Interactive Model Data Analysis 
The purpose of this interactive analysis is to find out the perceptions of the Minangkabau people in Nagari Kapau on Indigenous Wisdom (Local Wisdom) that are owned and used in decision making on the administration of the Nagari Kapau government.

\section{RESULTS AND DISCUSSION}

\section{Synergy of Indigenous Values (Local Wisdom) With Law Number 6 of 2014 Concerning Village on The Operation of Nagari Kapau Government In West Sumatera}

Based on the description of this research, not all customary values are owned and used in the implementation of the Nagari Government. However, the customary values used are based on Law Number 22 of 1999 concerning Regional Government [15], Law Number 32 of 2004 concerning Regional Government [16], Law Number 23 of 2014 concerning Regional Government [17], Law Number 9 of 2015 concerning Regional Government [18], Law Number 6 of 2014 concerning Villages [3] and Provincial Regional Regulations Number 9 of 2000 [19] and Provincial Regional Regulations Number 2 of 2007 concerning Basic Provisions of the Nagari Government [20], Provincial Regional Regulations Number 7 of 2018 concerning Nagari [21] and Regional Regulations of Agam Number 31 of 2001 concerning the Nagari Government [22] for the implementation of the Nagari Kapau Government.

The values of the Nagari adat that are used in the implementation of the Nagari Kapau Government are as follows:

\section{Residents of Nagari Kapau}

Residents of Nagari Kapau Geneologically, Nagari Kapau residents have institutionalized blood ties in organizing Nagari Kapau, even though they live outside of Kapau such as in Java, Kalimantan and Overseas (Singapore and Europe) but remain as Kapau citizens, whose rights and obligations remain valid as children Nagari Kapau is like choosing Wali Nagari.

\section{Nagari Kapau Religion}

Based on the philosophy of "Adat Basandi Syara" Syara' "Basandi Kitabullah" used in the administration of the Nagari Kapau Government (a) Nagari Nagari Kapau's son must be an Islamic religion, then Niniak Mamak (Chieftain) recog nized it as a child of his descendants (b) the religion in Nagari Kapau is a single religion, namely Islam. If there is an Islamic religion, then it is not recognized in the tribe and its people (c) to be a candidate for guardian Nagari, the conditions must be Muslim. This has already been established and the administration of Nagari and Wali Nagari has only been deter mined. This is based on the Nagari traditional thimble law set out by Datuk Parpatih Nan Sabatang as in the Minangkabau adat philosophy; Adat Basandi Syarak, Syarak Basandi Kitabullah (Adat coded Syarak, Syarak Coded Kitabullah).

\section{Nagari Tribe}

Nagari Kapau has nine tribes namely the Gadang, Koto, Jambak Malayu, Guci, Pili, Tanjung, Banana and Simabua tribes. However, only 6 tribes have duties and functions in carrying out (1) customary fields (Datuk Bandaro) (2) Syarak Field (Datuk Mangkudun) (3) Agriculture and Irrigation (Datuk Panduko Barasa) (4) Economy (Datuk Tandi Langik) (5) In Nagari (Indo Magarjo) (6) Security (Datuk Panglimo). To establish a Nagari, one must meet the requirements (1) there are four tribes, (2) each tribe has several stomachs (maternal descent), (3) each tribe has a tribal leader who is a collective holder of the Nagari Government, (4 ) Batungganai house is having clan head or family head who inhabit the house according to the matrilineal system [23], [24].

\section{Nagari land}

Niniak Mamak (Chieftain) Customary Charter KeNagarian Kapau Years 1912, 1925, 1955, 1997 and 2003 stipulated that (1) Land should not be certified, only adat letters and their boundaries were issued by Niniak Mamak (Chieftain). (2) Sako Pusako such as houses, land, rice fields and fields may not be sold to outsiders other than Kapau residents, if anyone sells other than Kapau Nagari residents, they will get customary sanctions. However, if there is a violation of paying the debt as stipulated in the charter Nagari Kapau. 


\section{Niniak Mamak (Chieftain)}

The role of Niniak Mamak (Chieftain) (1) Niniak Mamak (Chieftain) is the Owner of Nagari (2) proposing candidates for Wali Nagari to be elected by the community (3) giving input to Wali Nagari in compiling and managing the Nagari Government program (4) issuing letters regarding Sakko, Pusako and Sangsako Nagari.

\section{Nagari Justice}

The Nagari Kapau traditional court consists of three parts namely; adat court, Syarak and Sako Pusako. That is; (1) if the case is in the customary field, then Datuk Bandaro completes (2) if the case is in the field of Sharak, then Datuk Mangkudun resolves. However, if there is a problem with Soko Pusako, then the Niniak Mamak (Chieftain) VI tribe who regrets and the guardian of the Nagari is only the facilitator of the litigant child who is litigant.

\section{Nagari Government and Nagari Customary} Institution

Nagari Kapau Government Institutions namely (1) Wali Nagari as head of Nagari Government (2) Nagari Secretary is a Civil Servant assigned by local government (3) Head of Government affairs (4) Head of Development affairs (5) Head of Social Affairs (6) Head Financial and Asset Affairs (7) Treasurer (8) Kepala Jorong (Chairman of the community environment). This Nagari Government Institution has the same function as the Village Government as the Village Administration. Also, there are traditional Nagari institutions namely (1) Nagari Indigenous Density (KAN) (2) Nagari Community Empowerment Institution (LPMN) (3) Nagari MUI (4) Nagari PKK (5) Naguang Nagari Bundo (6) Parik Paga Nagari (7) Nagari Youth Organization. This institution comes from the Nagari community, its tasks, and functions as a social function and empowerment of the Nagari community.

Based on the description of customary values based on the values of origin, history of its establishment, area of origin, region, culture, community, ethnicity, which is owned and is still maintained in Nagari Kapau in the practice of governing Nagari, long before the Unitary State of the Republic of Indonesia (NKRI) became a country. In fact, despite the uniformity of villages throughout Indonesia based on Law Number 5 of 1979 concerning the Village Government. However, Nagari Kapau still has, maintains and uses traditional values in the administration of Nagari government until now. The preservation of Nagari's traditional values as social capital is a manifestation of high civic virtue that can help the realization of good governance. This social capital, including the values of mutual trust, tolerance, cooperation, mutual respect, and shared responsibility so as to help the realization of a more democratic government [25].

Referring to the 1945 Constitution of the Republic of Indonesia in Article 18B paragraph (1), the State accepts and respects special or specially designed local government units that are regulated by law (2) adat along with its traditional rights as long as they are still alive and in accordance with the development of society and the principles of the Unitary State of the Republic of Indonesia, governing in law. However, if it relates to indigenous and tribal peoples related to indigenous and tribal peoples, changes to the understanding of organic communities that use their functions through their governance organizations as instruments of indigenous peoples [26].

The implementation of Nagari governance based on local wisdom is in accordance with the characteristics of regional autonomy policies, that are in line with the rationality of decentralization policies. Political aspects assess the importance of decentralization for the interests of national politics and local communities. The importance of national politics with decentralization policies is very important to improve: (1) political education for local communities, (2) training ground, for local political leadership, (3) strengthening political stability (Smith, 1985). However, on the other hand, that the interests of local communities, decentralization is very important and beneficial to improve; (1) political equality (2) accountability (3) responsiveness governance. Therefore, that the implementation of regional autonomy is the discretionary power of the local government to organize self-government based on the initiative, creativity and active participation of the community in order to 
develop and advance their regions. That is, local communities have the right to determine their own destiny and try to improve their own destiny through community empowerment [27].

Thus, that the Nagari administration in West Sumatra as the lowest government is based on customary values that are owned and used as indigenous peoples' unity not formed by the State but formed by the community concerned through a long process of tens or even hundreds of years ago., as stated [28]. The formation of the traditional village government, too) 1) strengthen community participation (2) have a responsive and participatory government (3) for the creation of community welfare such as Nagari Kapau is still a Nagari Luhak (original Nagari) whose Nagari administration is still based on adat, not village formed by the District and City Governments [29].

However, that the administration of the Nagari government based on Law Number 6 of 2014 concerning Villages, has not yet shown synergy between customary values and optimal regional autonomy because there is no Agam regency regional regulation governing it. in connection with the issuance of the provincial regulation number 7 of 2018 concerning Nagari. Therefore, the implication is the use of customary values in organizing Nagari Government and synergizing with Law Number 6 of 2014 concerning Villages based on the principle of (a) legal certainty (b) orderly governance (c) orderly public interest (d) openness (e) proportionality (f) professionalism (g) accountability (h) effectiveness and efficiency (i) local wisdom (j) diversity; (k) and participatory. Thus, the use of traditional values to strengthen the course of the Nagari Kapau government following the origin, history, ethnicity, culture, region, region and community characteristics.

\section{CONCLUSIONS}

Based on the description of the findings of this study that had been revealed previously, that in the implementation of the Nagari Kapau Government in Agam Regency, West Sumatra Province, a synergy of customary values was found with Law Number 6 of 2014 concerning Villages. However, it has not been maximized because there is no Agam district government regulation governing it. As for the traditional values (local wisdom) which are synergized with Law Number 6 of 2014 concerning Villages as the findings of this study are as follows:

1. Residents of Nagari Kapau, Nagari residents have blood ties that have been institu tionalized in organizing Nagari Kapau, even though they live outside Nagari Kapau such as in Java, Kalimantan and Overseas (Singapore and Europe), however, they remain as Nagari Kapau citizens, have rights and his obligations remain valid as a child of Nagari Kapau such as choosing Wali Nagari (Head of the Customary Village).

2. Nagari Kapau Religion, Nagari Kapau has a traditional philosophy, namely: "Adat Basandi Syara" Syara "Basandi Kitabullah" used in the administration of Nagari Kapau Government. Religion in Nagari Kapau is a single religion that is Islam, meaning (a) to become a child Nagari Kapau must be Muslim then recognized by Niniak Mamak (Chieftain) as his child Kemanakannya (niece) (b) if they are not Muslim then they are not recognized in the tribe and their people (c) to become a candidate for Wali Nagari the conditions must be Muslim and it has become an institu tionalized rule in the Nagari Government in determining the Wali Nagari.

3. Nagari Kapau, Nagari Kapau has nine tribes, namely the Gadang, Koto, Jambak Malayu, Guci, Pili, Tanjung, Banana and Simabua tribes. Implementing Niniak Mamak (Chieftain)VI tribal customary values (1) Customary field (Datuk Bandaro) (2) Syarak Field (Datuk Mangkudun) (3) Agriculture and Irrigation (Datuk Panduko Barasa) (4) Economy (Datuk Tandi Langik) (5) In Nagari (Indo Magarjo) (6) Security (Datuk Panglimo).

4. Nagari Kapau Land, based on the Niniak Mamak (Chieftain) Charter Nagari Kapau or the Nagari Kapau Customary Law 1912, 1925, 1955, 1997 and 2003 stipulates that (1) Land must not be certified, only customary letters 
and boundaries are issued by Niniak Mamak (Chieftain). (2) Sako Pusako (Harta Warisa) such as houses, land, rice fields and fields may not be sold to outsiders other than residents of Nagari Kapau. However, if there is a violation of paying debt as stipulated in the charter.

5. Niniak Mamak (Chieftain) and Role of Niniak Mamak (Chieftain) Nagari Kapau are (a) Niniak Mamak (Chieftain) is the Owner of Nagari (b) proposes candidates for Wali Nagari to be elected by the Community (c) provides input to the Wali Nagari in compiling and managing regarding Sakko, Pusako and Sangsako (inheritance assets) which is passed down from generation to generation). Structure of Niniak Mamak (Chieftain) VI tribe in Nagari Kapau (a) Customary field (Datuk Bandaro) (b) Syarak Field (Datuk Mangkudun) (c) Agriculture and Irrigation (Datuk Panduko Barasa) (d) Economy (Datuk Tandi Langik) (e) In Nagari (Indo Mangarajo) (f) Security (Datuk Panglimo).

6. Nagari Kapau Court, if a case occurs in Nagari Kapau community (1) if the case is in the customary field, then Datuk Bandaro (Customary field) will settle it (2) if the case is in the field of Syarak (Islamic law) then, Datuk Mangkudun (Syarak Field) who solved the problem. However, if there is a problem with Soko Pusako (inheritance), then the Niniak Mamak (Chieftain) VI tribe who regrets the problem and Wali Nagari are only facilitators from the Nagari community who are litigants.

7. Nagari Government Institutions and Nagari Customary Institutions, while the Nagari Government Institutions, namely (a) Nagari Mayor as Nagari head of government (b) Nagari Secretary is a Civil Servant assigned by the local government (c) Head of Government Affairs (d) Head of development affairs (e) Head of social affairs (f) Head of financial and Asset affairs (g) Treasurer (h) Wali Jorong. while the Nagari traditional institutions are (a)
Nagari Kapau Indigenous Density (b) Nagari Kapau Community Empowerment Institute (LPMN) (c) Nagari Kapau Indonesian Ulema Council (MUI) (d) Nagari Kapau Family Welfare Empowerment (PKK) (e) Kanduang Nagari Kapau (f) Parik Paga Nagari Kapau (g) Nagari Youth Organization.

8. The traditional values owned and used by Nagari Kapau have not been fully implemented based on the principle of local wisdom as stipulated in Law No. 6 of 2014 concerning Villages. However, thus Law No. 6 of 2014 has become the basis for imple menting local wisdom formally and researchers further need to examine the use of local values as social capital.

\section{ACKNOWLEDGMENTS}

Acknowledgments, the authors submit to the Institute of Research and Community Service (LP2M) of Universitas Negeri Padang for PNBP research funding in the fiscal year 2019 Contract Agreement Number 743/UN35.13/LT/2019, The author also thanks Nagari Kapau, the government of Agam district which is the location of this study and thanks to the research team.

\section{REFERENCES}

[1] C. Simabura. (2013). Nagari's position in the Indonesia State Administration System. Jurnal Ilmu Hukum Yustisia, 20(1).

[2] Law Number 5 of 1979 Concerning Village Government. (1979). Jakarta: Indonesia.

[3] Law Number 6 of 2014 Concerning Villages. Jakarta: Indonesia. (2014).

[4] A. Suryono. (2012). Democracy and Indonesian Lical Wisdom. Malang: UB Pres.

[5] H. Malau. (2016). Implementation of Regional Government: Synergy of Indigenous Values and Regional Autonomy in Nagari Government in West Sumatera. Penguatan Ilmu Sosial 
dan Humanioran Perbaikan Karakter Bangsa Indonesia, Padang.

[6] F. Benda-Beckmann and K. von BendaBeckmann. (2013). Political and Legal Transformation of an Indonesia Polity: The Nagari from Colonisation to Decentralisation. Cambridge: Cambridge University Press.

[7] B. C. Smith. (1985). Decentralization: The Territorial Dimension of The State. London: George Allen \& Ulwin.

[8] M. A. Muthalib and M. A. Ali Khan. (1982). Theory of Local Government. New Delhi: Sterling Publishers Private Limited.

[9] Y. S. Lincoln and E. G. Guba. (1985). Naturalistic Inquiry. Beverly Hills: Sage Publication London.

[10] D. E. McNabb. (2002). Research Methods in Public Administration and Nonprofit Management: Quantitative and Qualitative Approaches. New York: Sharpe, Inc.

[11] L. J. Moleong. (2010). Qualitative Research Methedology. Bandung: PT Remaja Rosdakarya.

[12] D. Brown. (2004). Why Independence? The Instrumental and Ideological Dimension of Acehnese Nationalism. Asia Research Center Working Paper, 105, pp. 1-21.

[13] N. U. Vipriyanti. (2008). Banjaar and Local Wisdom: Community Management for Public Space Sustainability in Bali Province. Biennial Conference.

[14] M. B. Miles, H. M and J. Saldana. (2014). Mixed Research Methodology. Yogyakarta: Pustaka Pelajar.

[15] Law Number 22 of 1999 concerning Regional Government. (1999). Jakarta: Indonesia.

[16] Law Number 32 of 2004 concerning Regional Gocernment. (2004). Jakarta: Indonesia.
[17] Law Number 23 of 2014 concerning Regional Government. (2014). Jakarta: Indonesia.

[18] Law Number 9 of 2015 concerning Regional Government. (2015). Jakarta: Indonesia.

[19] Provincial Regional Regulations Number 9 of 2000 concerning Basic Provisions of the Nagari Governmnet, Padang: West Sumatera Province, 2000.

[20] Provincial Regional Regulations Number 2 of 2007 concerning Basic Provisions of the Nagari Government. (2007). Padang: West Sumatera Province.

[21] Provincial Regional Regulations Number 7 of 2018 concerning Nagari. (2018). Padang: West Sumatera Provience.

[22] Regional Regulations of Agam Number 312001 concerning the Nagari Government. (2001) Lubuk Sikaping: Agam Regency.

[23] M. S. Amir. (1997). Minangkabau Customs, Minang People's Purpose and Lifestyle. Jakarta: Mutiara Sumber Widya.

[24] S. Takano. (2018). Political and Legal Transformation of an Indonesian Polity: The Nagari from Colonization to Decentralization. Book Review: Polar Online. 1-3. doi: 10.1111/plar. 12229.

[25] R. Putnam. (1993). Making Democracy Work. Princeton: Princeton University Press.

[26] M. Sirait, C. Fay and A. Kusworo. (1999). How Customary Law Community Rights in Managing Natural Resources are Regulated. Southeast Asia Policy Research Working Paper, 24, pp. 1-67.

[27] H. A. Widjaja. (1998). Regional Autonomy Pilot in Indonesia. Jakarta: Rineka Cipta.

[28] W. Azwar, Y. Yunus, Muliono and Y. Permatasari. (2018). Nagari Minangkabau: The Study of Indigenous Institutions in West Sumatera, 
Indonesia. Jurnal Bina Praja, 10(2), pp. 231-239.
[29] H. Malau. (2013). Good Governance Implementation In Nagari Government In West Sumatera. Tingkap, 9(2). 